\title{
液状化地盤において鉛直荷重を受ける鋼管単杭の曲げ座屈応力度 BUCKLING STRESS OF STEEL PILE WITH VERTICAL LOAD IN LIQUEFIED SOIL
}

\author{
木村祥裕*1, 時松孝次*2 \\ Yoshihiro KIMURA and Kohii TOKIMATSU
}

\begin{abstract}
When slender steel piles beneath buildings experience high axial compression forces as a result of vertical loads increased by P- $\Delta$ effects with inertia forces acting on the buildings and then the soil liquefies, buckling of the piles may occur even thought they are restrained laterally by the liquefied soil. This paper describes the evaluation of the buckling length of slender piles in liquefied soil with the unified and triangular distributions of the coefficient of the subgrade reaction. The relationship between the buckling length of the slender piles and the soil-pile interaction is presented.
\end{abstract}

\section{Keywords : Steel Pile, Flexiable Buckling Length, Coefficient of Subgrade Reaction, liquefaction, Energy Method, FEM Analysis \\ 鋼管杭，曲げ座屈長さ，地盤反力係数，液状化，エネルギー法，有限要素解析}

\section{1. $\quad$ 索}

性能設計法の導入により，上部構造のみならず杭基蓬におい ても, 想定される地震外力に対して, 保有耐力及び塑性変形性 能を明確にする必要性が増してきている。このため，杭基整の 塑性化を許容し，大変形時においても耐荷能力を維持できる鋼 管杭等の高勒性部材の有効性が再確認されている。

しかし，「建築耐震設計における保有耐力と変形性能 1990 」" では，銅管杭について局部座屈に対する径厚比制限を設けている ものの，軸圧縮荷重に対しては支持力の検討だけで，曲げ座屈 に対する細長比制限等を規定していない。これは，一般に軟弱 地盤であっても, 地盤は杭の曲げ座屈に対して水平変形を十分 に拘束することができると考えられているためである。しかし， 地震時に地盤が液状化した場合，水平地盤反力倸数が大幅に低 下するため，杭の曲げ座屈に対して地盤の変形拘束効果はほと んど期待できなくなる。さらに，地震時に上部構造物の慣性力 によって生じる転倒モーメントが偶力として杭に作用すると， 上部構造物の自重だけが杭に作用する場合と比べて，圧縮応力 の大幅な増加が予想されることから，細長比の大きい杭は曲げ 座屈を生じる可能性がある。

既往の研究 2)では地盤の液状化時に杭の側方変位の影響を考虑
して, 地盤反力と杭の弾性座屈荷重の関係を示している。しかし, 鋼管杭の曲げ座屈に対して，杭の材料特性及び地盤反力変位関 係等の非線形挙動や地盤反力係数分布の影響を検討しておらず, 水平変形拘束を受ける杭の曲げ座屈長さを把握するに至ってい ない。

本研究では，地震時に液状化により地盤反力係数が低下した場 合に, 上部構造物の自重及び転倒モーメントによる偶力等の鉛直 荷重を受ける鎆管杭の曲げ座屈荷重に及ぼす地盤反力係数分布の 影響を明らかにする。杭の曲げ座屈荷重をエネルギー法により求 め, 弾性固有值解析及び地盤と鋼管杭の非線形挙動を考虑した弾 塑性大変形解析を行い，その妥当性を検証する。さらに地盤によ り水平変形拘束を受ける鋼管杭の曲价座屈長さを提示する。本論 文は， 2 章: 弾性曲げ座屈荷重の提示， 3 章 : 地盤反力係数の非線 形性を考慮した低減係数の評価, 4 章 : 液状化地盤中の弾塑性曲げ 座屈応力度の評価法の提案で構成されている。

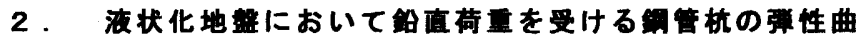 げ座届荷量}

本章では, 液状化地盤において鉛直荷重を受ける鋼管杭の弾性 座屈荷重式を誘導し，地盤反力係数分布の違いが座屈荷重に与え

\footnotetext{
*1 長崎大学工学部構造工学科 助教授・博士 (工学)
}

*2 東京工業大学大学院建築学尃攻 教授・工博
Assoc. Prof., Dept. of Structural Engineering, Faculty of Eng., Nagasaki University, Dr. Eng.

Prof., Dept. of Architecture and Building Engineering, Graduate School of Tokyo Institute of Technology, Dr. Eng. 
る影響について検討する。

\section{1 管杭の毫性曲げ座風の仅定条件}

液状化地盤において，地盤により水平変形拘束を受ける鋼管杭の 曲げ座屈荷重を算定するために，以下の仮定を用いる。

1) 杭は単杭とする。

2）杭に作用する外力は図 1 に示すように鉛直荷重のみとする。

3) 杭の材端支持条件は通常の圧縮材と同様, 座屈荷重を安全側と して評価するために単純支持とし，杭頭の移動は考えない。

4）水平地盤反力係数を図 1 のような水平変形に対する弾性バネに 置換する。

5）杭に作用する単位長さ・杭幅当たりの地盤反力保数を次式とす る。

$$
\begin{aligned}
& K_{\mathrm{c}}=\mathrm{k}_{\mathrm{h} 1} \mathrm{~B}\left(\mathrm{MN} / \mathrm{m}^{2}\right) \\
& \mathrm{k}_{\mathrm{h} 1}=80 \mathrm{E}_{0} \mathrm{~B}^{-\frac{3}{4}}\left(\mathrm{MN} / \mathrm{m}^{3}\right)
\end{aligned}
$$

ここで, $k_{h 1}$ は文献 3 ) に示される地盤反力係数で, 変形係数 $\mathrm{E}_{0}$ 及 び鋼管径 Bから求められる。ただし， $\mathrm{k}_{\mathrm{h} 1}$ の式中のB は $\mathrm{cm}$ で表示さ れた無次元量である。本解析で用いる $K_{\mathrm{c}}$ の值は $0.01 ， 0.1 ， 1 \mathrm{MN} / \mathrm{m}^{2}$ である。本論文で使用した $K_{\mathrm{c}}$ と $\mathrm{E}_{0}$ の関係は，表 1 に示寸通りである。 6) 地盤反力係数分布は図 2 に示すように，梁度方向に( i ) 等分 布, ( ii ) 三角形分布とする。それぞれの場合の $K$ は次式で表される。 (i 等分布

$$
K=K_{\mathrm{c}}
$$

(ii) 三角形分布

$$
K=2 K_{\mathrm{c}} \frac{x}{l}
$$

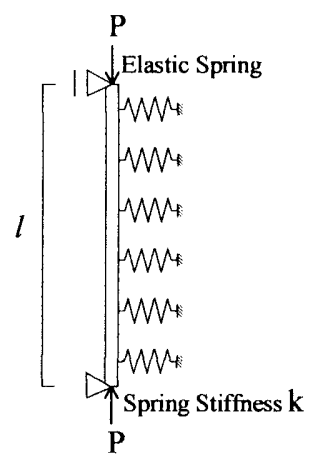

表 1 単位長さ・杭幅当たりの 地盤反力係数 $K_{\mathrm{c}}$ と変形係数 $\mathrm{E}_{0}$

\begin{tabular}{|c|c|}
\hline$K_{\mathrm{c}}\left(\mathrm{MN} / \mathrm{m}^{2}\right)$ & $\mathrm{E}_{0}\left(\mathrm{MN} / \mathrm{m}^{3}\right)$ \\
\hline 0.01 & 0.0047 \\
\hline 0.1 & 0.047 \\
\hline 1 & 0.47 \\
\hline
\end{tabular}

$\mathrm{B}=50 \mathrm{~cm}$ の場合

図 1 鉛直荷重を受ける鋼管杭及び 地盤解析モデル

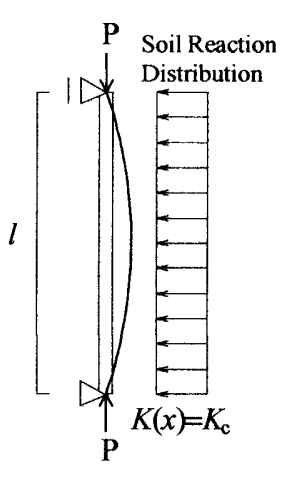

(i) 等分布

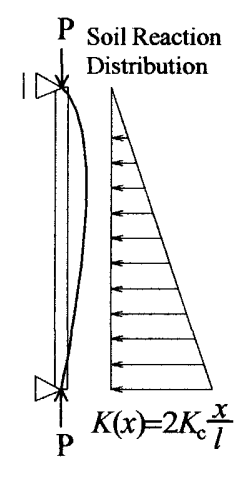

( ii ). 三角形分布
図 2 鋼管杭の曲价座屈変形と地盤反力係数分布

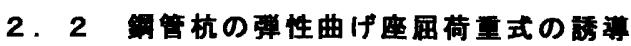

地盤による水平変形拘束を受ける鋼管杭が曲げ座屈するときのポ テンシャルエネルギーは文献 4) より次式となる。

$$
\mathrm{U}=\frac{1}{2} \int_{b}^{2}\left(\mathrm{El} u^{\prime \prime 2}-\mathrm{P} u^{12}+K u^{2}\right) d x
$$

ここで, EI は鋼管杭の曲げ岡性，P は鉛直荷重であり， $K$ は (2) 式ま たは (3) 式に示す通りである。lは材長, $x$ は材軸の座標, $u$ は座屈変 形である。

（i ）地盤反力係数分布が等分布である場合 地盤反力係数分布が等分布の場合，(4) 式にお怰る $K$ を(2)式とし，座 屈変形を近似的に次式とする。

$$
u=a \sin \frac{n \pi x}{l}
$$

ここで, $n$ は座屈波数, $a$ は振幅である。(4) 式を変分し, 釣り合い方 程式を求めると，座屈荷重 $\mathrm{P}_{\mathrm{cr}}$ は次式となる4)。

$$
\mathrm{P}_{\mathrm{or}}=\left(\frac{\pi}{l}\right)^{2} \mathrm{EI} \alpha
$$

ここで， $\alpha$ は地盤による座屈荷重の上昇率として次式で表される。

$$
\alpha=\mathrm{n}^{2}+\left(\frac{l}{\pi}\right)^{4} \frac{K_{\mathrm{c}}}{n^{2} \mathrm{EI}}
$$

$n$ は (6) 式の $\mathrm{P}_{\mathrm{cr}}$ が最小となる自然数であり， $K_{\mathrm{c}}=0$ の場合, 常に 1 と なる。そのとき， $\alpha=1$ となり，(6) 式は Euler 座屈荷重を表す。

（ii）地盤反力保数分布が三角形分布である場合

地盤反力俰数分布が三角形分布の場合，(4) 式における $K$ は等分布 の場合と杭中央で值が等しくなる $(3)$ 式を用いる。杭の座屈変形に対 する地盤反力係数は材軸方向に一様でないため, 座屈変形を近似的 に次式のように仮定する。

$$
u=a \sin \frac{\pi x}{l}+b \sin \frac{2 \pi x}{l}
$$

(3)，(8) 式を用いて (4) 式を変分し，釣り合い方程式を求めると，座 届荷重 $\mathrm{P}_{\mathrm{cr}}$ は次式となる。

$$
\begin{aligned}
\mathrm{P}_{\mathrm{cr}} & =\frac{5}{2}\left(\frac{\pi}{l}\right)^{2} \mathrm{EI}+\frac{5}{8}\left(\frac{l}{\pi}\right)^{2} K_{\mathrm{c}} \\
& -\sqrt{\frac{9}{4}\left[\left(\frac{\pi}{l}\right)^{2} \mathrm{EI}-\left(\frac{l}{\pi}\right)^{2} \frac{K_{\mathrm{c}}}{4}\right]^{2}-\frac{256}{81} \frac{K_{\mathrm{c}}^{2}}{l^{4}}\left(\frac{l}{\pi}\right)^{8}}
\end{aligned}
$$

ただし，(8) 式は 1 次の座屈モードの近似式であることから, (9) 式の 適用範囲は $\mathrm{P}_{\mathrm{or}}$ の極小值以下となる。 $K_{\mathrm{c}}=0$ の場合, (9) 式も (6) 式と同 様, Euler 座屈荷重を表す。

\section{3地盤による水平変形拘束を受ける策管杭の彈性曲 げ庶用荷量}

前節でエネルギー法より求めた曲げ座屈荷重式を弾性固有值解析 5)により検証する。杭を材長方向に50 分割した線材要素でモデル化 し，地盤反力係数を水平変位に対するバネに置換する。バネ剛性 $\mathbf{k}$ は地盤反力係数 $\mathrm{k}_{\mathrm{h} 1}$ に鋼管径 $\mathrm{B}$ 及び杭単位長さに対するばね要素間の 距離 $d$ の比を乗じることで $\mathrm{k}=\mathrm{k}_{\mathrm{h} 1} \mathrm{~B} d(\mathrm{MN} / \mathrm{m})$ として求められる。

図 3 (a) にエネルギ一法及び弾性固有值解析から求めた座屈応力度 と細長比との関係を示す。縦軸は弾性座屈荷重 $\mathrm{P}_{\mathrm{cr}}$ を杭の断面積 $\mathrm{A}$ で 除した弾性曲げ座屈応力度 $\sigma_{\mathrm{cr}}$, 横軸は杭の細長比 $\lambda(=l / i)$ である。細 破線は(6) 及び (7) 式, 細実線は (9) 式から求められる座屈曲線で 
あり，曲げ座屈荷重が最小となる波数 $\boldsymbol{n}$ について示している。また， オイラー座屈曲線を併記している。 分布及び三角形分布の場合の弾性固有值解析結果である。 $K_{\mathrm{c}}=0.01 \mathrm{MN} / \mathrm{m}^{2}$ の場合, $\lambda \leqq 150$ の範囲で $\mathrm{s}$ in 半波である 1 次モードが 卓越しており, 各式から求められる曲げ座屈荷重はほほ等しくなっ ている。 $K_{\mathrm{c}}$ が大きくなるに従い, 最小曲げ座屈荷重を与える座届変 形は高次モードへと移行していく。特に $\lambda \leqq 150$ で高次モードが卓 越する $K_{\mathrm{c}}=1 \mathrm{MN} / \mathrm{m}^{2}$ の場合, 地盤反力倸数分布の違いが曲げ座屈荷重 に及ぼす影響は大きくなり，等分布 $(O)$ に比べて三角形分布（ $(\square ）$ では座屈荷重が最大 $20 \%$ 程度小さくなっている。また, 図 3 (b)に 等地盤反力係数分布の座屈荷重式で採用されている波数 $n$ を示す。 $K_{\mathrm{c}}$ が大きいほど, 細長比が大きくなるに従って, 座屈波数 $n$ は増加 し, 高次モードへと移行するが， $K_{\mathrm{c}}$ が小さい場合， $n$ は 1 である。本 論文で提示した単純支持の曲げ座届荷重式と数値解析結果は概ね対 応しており, 前節でエネルギー法により求められた曲げ座屈荷重式 の有効性が示されている。

従って，これらの座屈荷重式はある程度の精度があると考えられ るが, 座屈モードを一つもしくは二つの波形で仮定しているため, $K_{\mathrm{c}}$ が大きい場合, 細長比が大きくなるに従って, 座屈応力度が単調 には小さくならず，一部で大きくなる現象が生じている。これは, 実際の弾塑性座屈とは異なる傾向であり，(6)，(7)，(9) 式に対応し, かつ数值解析結果に対応したより簡便で害用的な近似式を提示寸る。

地盤反力係数分布が等分布の場合, $l$ に関する $(6)$ 式の極小值は次 式となり, $n=1$ で $\mathrm{P}_{\mathrm{er}_{\mathrm{r}}}$ が極小值となるときの $l$ よりも大きい範囲 $\left(l \geq \pi \sqrt[4]{\mathrm{E} \mathrm{I} / K_{\mathrm{c}}}\right)$ で座屈荷重の下限値を次式とする。

$$
\mathrm{P}_{\mathrm{cr}}=2 \sqrt{\mathrm{EI} K_{\mathrm{c}}} \quad\left(l \geq \pi \sqrt[4]{\mathrm{EI} / K_{\mathrm{c}}}\right)
$$

(10)式を(6)式の形で表すと， $\alpha$ は次式となる。

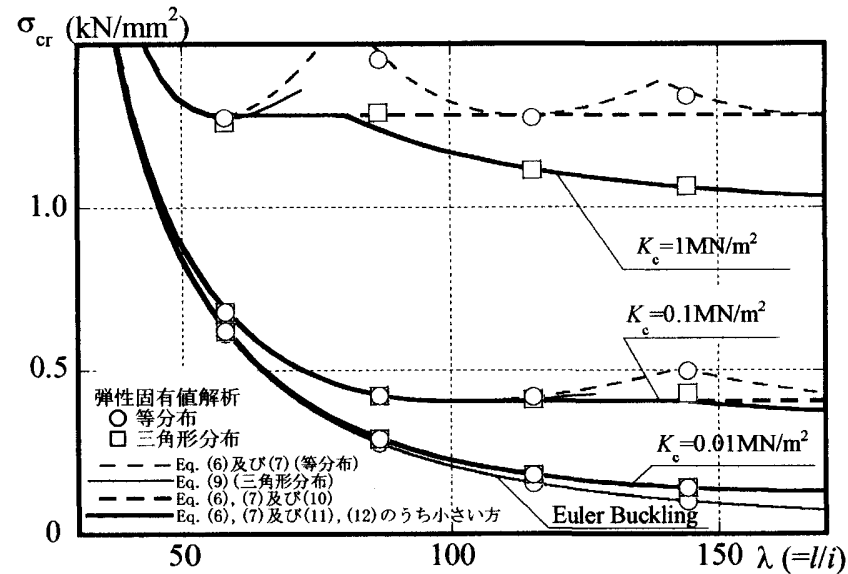

図 3（a）地盤反力係数分布が異なる鋼管杭の 弾性曲げ座屈态力度

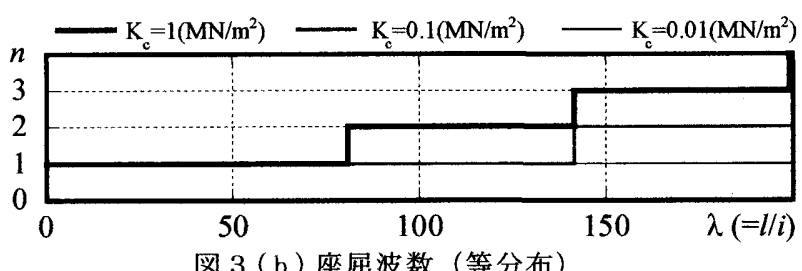

図 $3(\mathrm{~b})$ 座屈波数（等分布）

$$
\alpha=2\left(\frac{l}{\pi}\right)^{2} \sqrt{\frac{K_{\mathrm{c}}}{\mathrm{EI}}}
$$

また, 三角形分布の場合, 同様に(6) 式において極小值までは(7) 式, $\pi \sqrt[4]{\mathrm{EI} / K_{\mathrm{c}} \leq} \leq \pi \sqrt[4]{2 \mathrm{EI} / K_{\mathrm{c}}}$ の場合, (11) 式とする。 $l \geq \pi \sqrt[4]{2 \mathrm{EI} / K_{\mathrm{c}}}$ の場 合, 次式を用いて, 曲げ座屈荷重を近似する。

$$
\alpha=1+\frac{3}{2}\left(\frac{l}{\pi}\right)^{2} \sqrt{\frac{K_{\mathrm{c}}}{\mathrm{EI}}} \quad\left(l \geq \pi \sqrt[4]{2 \mathrm{EI} / K_{\mathrm{c}}}\right)
$$

図 3 中の太実線及び太破線は, (6) 式の $\boldsymbol{\alpha}$ に(11)，(12) 式の等分布, 及び三角形分布の場合の近似式による曲線である。

\section{3.液状化地盘において鉛直荷重を受ける成管杭の弹望性 曲げ座届性状}

実際の地盤は前章の仮定と異なり, 水平地盤反力係数は杭の水平 変位によって変化する。そこで, 杭の材料特性及び地盤反力変位関 係の非線形性を考虑した鋼管杭の弾塑性座屈性状及び弾塑性曲げ座 屈荷重を検討する。

\section{1 解析概要}

図 4 に鋼管杭の材料特性を示す。鋼管の応力歪関倸は文献6）の 引張試験結果を元にRound House 型にモデル化している。

図 5 に解析モデル5) を示す。鋼管杭の各節点にバネ要素を配置す ることで地盤反力倸数を表現している。バネ要素は水平方向の地盤 反力のみを伝達するものをする。また, 地盤反力係数分布は前章で 用いた等分布, 三角形分布とし, $K_{\mathrm{c}}$ の值は $0,0.01,0.1,1 \mathrm{MN} / \mathrm{m}^{2}$ で ある。

通常，杭の製作時及び施工時に生じるたわみを考慮して，図 6 に 示すような形状初期不整を杭に与える。初期不整は弾性固有值解 析から得られる 1 次, 2 次モ一ドを用い, 最大值を $l / 5000, l / 10000$ と している。

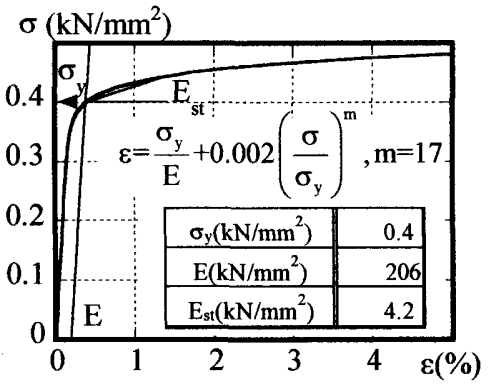

図 4 鋼材の材料特性

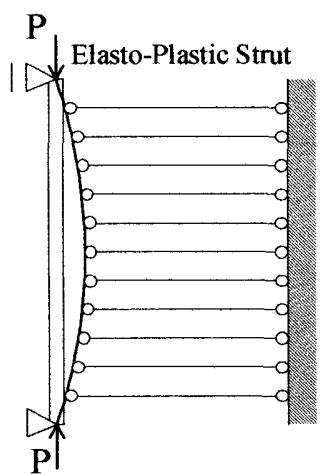

図 5 地盤による水平変形 拘束を受ける杭の弾 塑性解析モデル

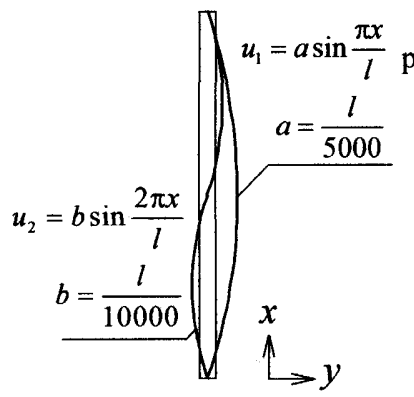

図 6 杭初期不整

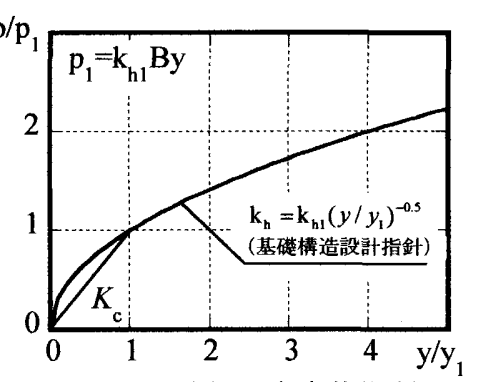

図 7 地盤反力変位関係 
図 7 に地盤反力変位関係を示す。ここで, 横軸は地盤の水平変位, 綐軸は地盤反力であり，基準変位 $\mathrm{y}_{1}$ 及び基準反力 $\mathrm{p}_{1}$ で無次元化して いる。地盤の非線形性を考慮するため, 地盤反力変位関倸が基礎構 造設計指針 ${ }^{7)}$ の設計式で表される非弾性地盤と， $K_{\mathrm{c}}$ が一定の弹性地 盤について検討する。非弹性地盤では，基準值 $\left(\mathrm{y} / \mathrm{y}_{1}, \mathrm{p} / \mathrm{p}_{1}\right)=(1,1)$ にお ける割線剛性を $K_{\mathrm{c}}$ としている。

\section{2 地盤特性の这いが成管杭の弹望性曲げ座届性状に 与える影事}

(i ) 地盤反力係数の違い

図 8 (a) 〜 (d) に細長比 $\lambda=115$ で地盤反力係数が異なる場合の杭の座 屈性状を示している。図 8 (a) に杭の平均軸応力ー 平均軸歪関係を示 す。繸軸は杭に作用する鉛直荷重 $\mathrm{P}$ を鋼管断面積 A で除した平均軸 态力 $\sigma_{x}$ であり，横軸は杭頭の鈆直変位を材長で除した平均軸歪 $\varepsilon_{x}$ を 百分率 (\%) で示している。地盤反力俰数分布は三角形分布である。地 盤反力係数が相対的に大きくなるにつれて銅管杭の最大荷重は上昇 しているものの, $K_{\mathrm{c}}=1 \mathrm{MN} / \mathrm{m}^{2}$ の場合でも座屈応力度は降伏応力度 $\left(\sigma_{\mathrm{y}}=0.4 \mathrm{kN} / \mathrm{mm}^{2}\right)$ の $80 \%$ 程度にしか達していない。また, $K_{\mathrm{c}}=0.01 \mathrm{MN} / \mathrm{m}^{2}$ の 場合, $K_{\mathrm{c}}=0 \mathrm{MN} / \mathrm{m}^{2}$ と比較して曲げ座屈荷重はほとんど上昇していな い。

図 8 (b) に平均軸歪と水平変位の関係を示す。綎軸は杭で最大とな る水平変位 $u$ を杭長 $l$ で除したものである。図中, 方座屈発生に伴 い，水平変位が急増する点であり， $K$ が小さいほど，座屈発生時の 軸歪は小さい。また, 座屈発生後の大変形領域 $\left(\varepsilon_{x} \geqq 0.15 \%\right)$ におい て $K_{\mathrm{c}}=0,0.01,0.1 \mathrm{MN} / \mathrm{m}^{2}$ における杭の水平変位はほぼ等しくなっている。 これは, 非弾性地盤の場合, 水平変位の増加に伴い地盤反力係数が 大幅に低下寸るためである。

図 $8(\mathrm{c})$ に最大荷重時における杭の水平变形分布を示す。綎軸は杭 の材軸方向の位置 $x$ を材長 $l$ で除したものであり，横軸は各位膡にお ける水平変位 $\boldsymbol{u}$ を材長 $l$ で除したものである。

図 $8(d)$ に最大荷重時における杭の作用曲げモーメント分布を示 す。繸軸は (c) と同様であり, 横軸は各位㯰における作用モーメント である。図中のムはそれぞれ，銅管杭の降伏モーメント $\mathrm{M}_{y}$, 全塑性

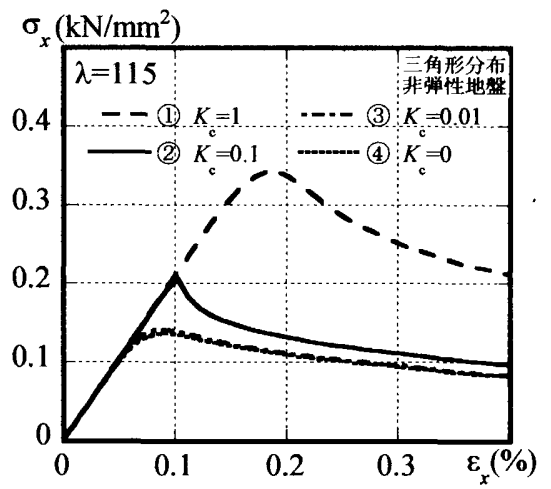

(a) 平均軸応力一平均軸歪関係

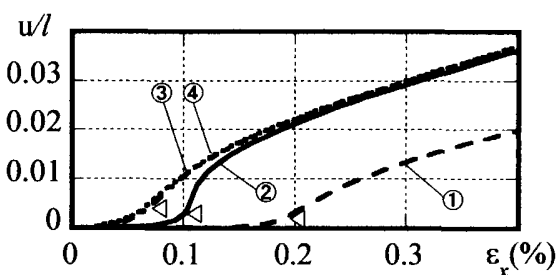

(b) 水平変位一平均軸歪関係

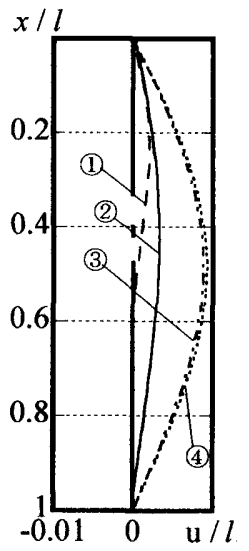

(c) 水平変形

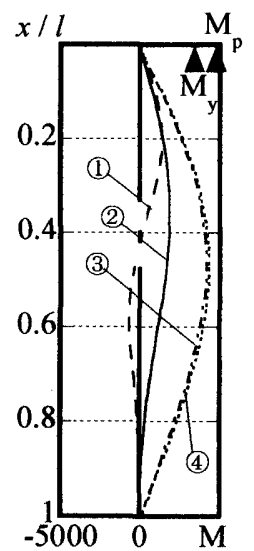

(d) 曲げモーメント

図 8 地盤反力係数值が異なる鋼管杭 の弾塑性曲げ座屈性状

(三角形分布, $\lambda=115$, 地盤非弾性)

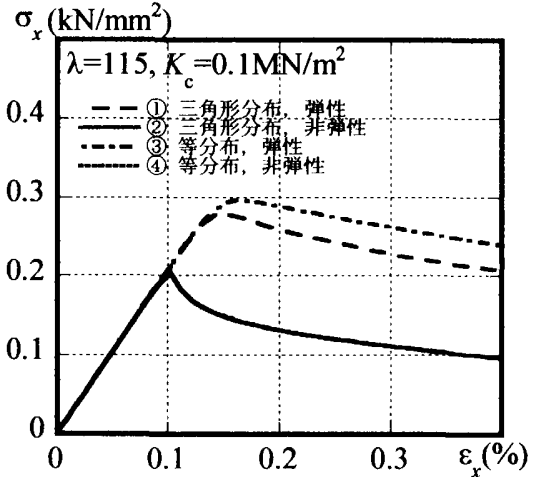

(a) 平均軸応力一平均軸歪関係

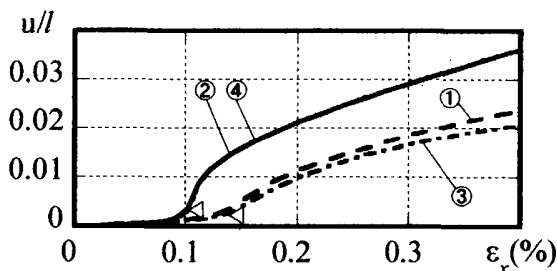

(b) 水平変位一平均軸歪関係
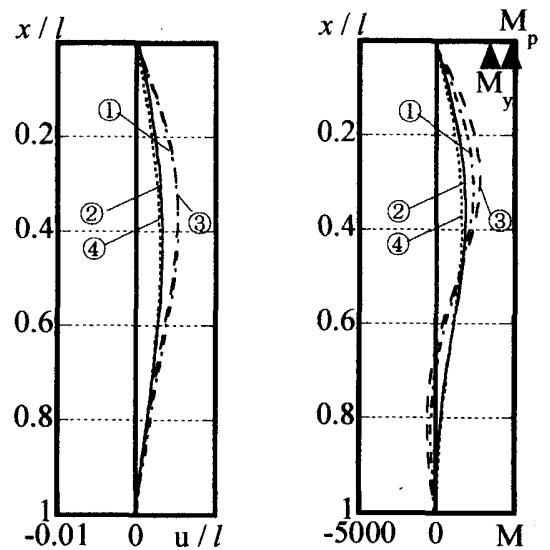

(c) 水平変形

(d) 曲げモーメント

図 9 地盤反力係数分布及び土圧一変 位関係が異なる鋼管杭の弾塑性曲げ座 屈性状 $\left(\lambda=115, K_{\mathrm{c}}=0.1 \mathrm{MN} / \mathrm{m}^{2}\right)$

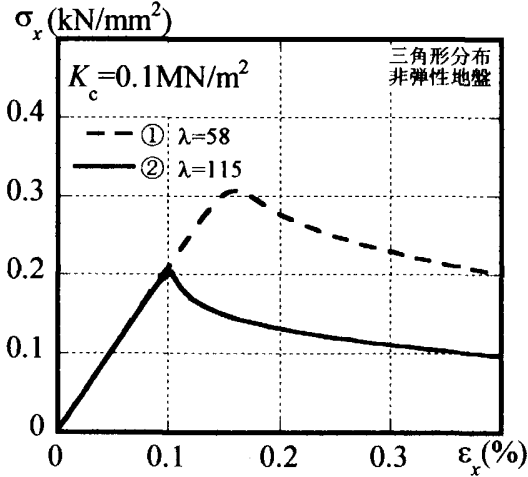

(a) 平均軸応力一平均軸歪関保

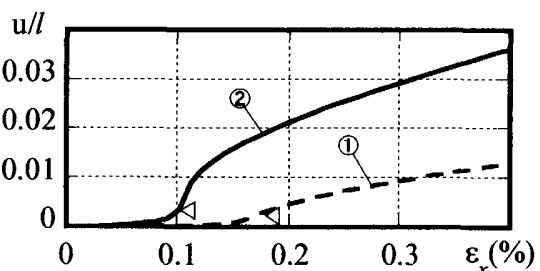

(b) 水平変位一平均軸歪関係

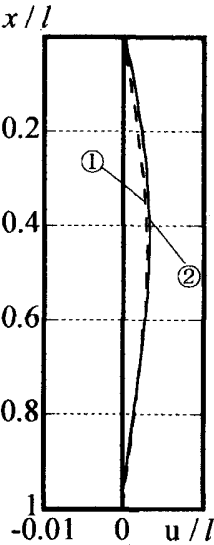

(c) 水平変形

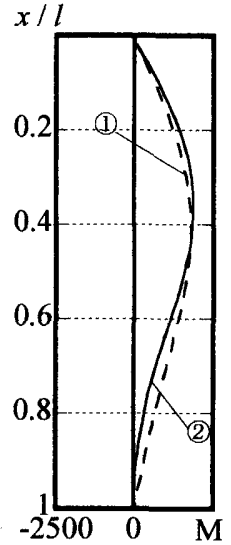

(d) 曲げモーメント
図 10 材長が異なる鋼管杭の 弾塑性曲げ座屈性状

$\left(K_{\mathrm{c}}=0.1 \mathrm{MN} / \mathrm{m}^{2}\right.$, 三角形分布，地盤非弾性 $)$ 
モーメント $\mathrm{M}_{\mathrm{p}}$ である。

地盤反力係数が小さい場合, 水平変形分布及び曲げモーメント分 布は杭中央で最大となる s i n 半波形となっており, 地盤反力係数が 小さくなるにつれて, 水平変形及び曲げモーメントの值は大きく なっている。地盤反力係数が相対的に大きい $K_{\mathrm{c}}=1 \mathrm{MN} / \mathrm{m}^{2}$ の場合, 水 平変形, 作用モーメントともに $l / 4$ の位置で最大となっており, 作用 モーメントは $2 l / 5$ より下では反転している。

（ii）地盤反力係数分布及び地盤反力変位関倸の違い

図 9 (a) (d) に細長比 $\lambda=115, K_{\mathrm{c}}=0.1 \mathrm{MN} / \mathrm{m}^{2}$ で地盤反力変位関係及び 地盤反力係数分布が異なる場合の杭の座屈性状を示している。図 9 (a)に杭の平均軸応力 - 平均軸歪関係を示す。地盤反力変位関係は弾 性及び非弹性であり，地盤反力係数分布は等分布及び三角形分布で ある。弾性地盤では等分布の場合の最大荷重は三角形分布の場合よ りも5\% 程度高いものの, 曲げ座屈が発生する時の平均軸歪はほぼ等 しい。また, 非弾性地盤では地盤反力係数分布の違いによらず, 平 均軸応力一平均軸歪関係はほぼ等しくなっている。弾性地盤に対し て非弾性地盤の最大荷重は7 0 \% 程度に低下している。

図 9 (b) に杭の平均軸歪と水平変位の関係を示す。弾性地盤に比へ て非弾性地盤では座屈が早期に発生するとともに座屈後の水平変位 は増加している。しかし, 地盤反力保数分布の違いによる水平変位 の差異はほとんど見られない。本章では非弾性地盤の初期勾配 $K_{\mathrm{c}}$ を 図 7 における $\mathrm{y} / \mathrm{y}_{1}=1$ の時の割線剛性と定義している。そして, 基礎 構造設計指針 ${ }^{8)}$ では $\mathrm{y}_{1}=1 \mathrm{~cm}$ としていることから， $K_{\mathrm{c}}$ は水平変位 $\boldsymbol{u}$ が $1 \mathrm{~cm}$ 時の剛性である。しかし, 実際に水平変形が急激に增大し, 座 屈が発生する時点での水平変位は図 $9(\mathrm{~b})$ に示す $\triangleleft の$ 位置で $u / l=0.002$ $\sim 0.003$ である。例えば $\lambda=115(l=2000 \mathrm{~cm})$ の場合, $u=4 \sim 6 \mathrm{~cm}$ に相当す る。つまり, 座屈時の地盤反力係数は図 7 の割線剛性 $K_{\mathrm{c}}$ よりも非常 に小さくなっているため, $K_{\mathrm{c}}=0.1 \mathrm{MN} / \mathrm{m}^{2}$ の非弾性地盤では地盤反力俰 数分布の違いが座屈性状にあまり影響を及ぼしていないものと思わ れる。

図 9 (c) に最大荷重時における水平変形分布を, 図 9 (d) に最大荷 重時におらる杭の作用曲げモーメント分布を示す。同じ軸歪時では 弾性地盤における杭の最大変形は非弹性地盤の場合よりも小さい。 しかし, 弾性地盤における杭の最大荷重は非弾性の場合よりも大き くなっており, そのときの杭の水平変形も弾性地盤の場合の方が 非弾性地盤の場合より大きくなっている。これは, 最大荷重に達す るまでの間に弾性地盤における杭の方がより大きな水平変形, 曲げ モーメントに耐えうることを示している。また, 弾性地盤では地盤 反力係数分布によらず, 杭頭から $l / 4$ の位置で水平変形が最大となっ ているが, 非弾性地盤ではs i n 半波の座屈変形となり, 弾性地盤と 比較して地盤による座屈拘束の効果は相対的に小さくなっている。 作用モーメントについても，弾性地盤では地盤反力係数分布によら ず，杭頭から $l / 4$ の位㯰で最大となっており，2l/3より下で作用モー メントが反転している。

（iii）液状化地盤の層厚の違い

図 $10(\mathrm{a}) \sim(\mathrm{d})$ に液状化地盤の層厚が異なる場合の杭の座屈性状を 示している。図 10 (a) に杭の平均軸応力ー 平均軸歪関俰を示す。ここ で想定している層厚は $10 \mathrm{~m}, 20 \mathrm{~m}$ であり, そのときの杭の細長比は $\lambda=58,115$ である。地盤反力係数分布は図 8 と同様, 三角形分布であ る。細長比の小さい $\lambda=58$ の杭の座屈応力度は $\lambda=115$ の杭よりも高い
ものの，降伏応力度には達していない。

図 10 (b) に杭の平均軸歪と水平変位の関係を示す。 $\lambda=115$ の杭に比べ て, $\lambda=58$ の杭では座屈後も水平変位の増加は緩やかである。

図 10 (c) に最大荷重時における杭の水平変形分布, 図 $10(\mathrm{~d})$ に作用 モーメント分布を示す。 $\lambda=58,115$ の杭ともに水平変形分布に大きな差 は見られないものの, 曲げモーメント分布では $\lambda=58$ の方がより sin 半 波に近くなっている。これは, 杭長の短い方が杭自体の曲げ剛性が高 く，地盤による座屈拘束が相対的に小さくなるためである。

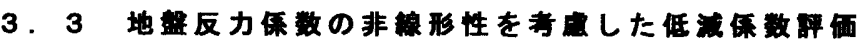

図 11 に弾性地盤と非弾性地盤における杭の最大荷重を示す。繸軸は 非弾性地盤における杭の曲げ座屈忘力度 ${ }_{\mathrm{ps}} \sigma_{\mathrm{cr}}$ に対する降伏応力度 $\sigma_{\mathrm{y}}$ の 割合であり, 横軸は弾性地盤における杭の曲げ座屈応力度 ${ }_{\mathrm{es}} \sigma_{\mathrm{cr}}$ に対す る降伏応力度 $\sigma_{\mathrm{y}}$ の割合である。各プロットは地盤反力係数 $K_{\mathrm{c}}=0.01 \sim 1 \mathrm{MN} /$ $\mathrm{m}^{2}$, 細長比 $\lambda=29 \sim 115$ (液状化層厚 $5 \mathrm{~m} \sim 20 \mathrm{~m}$ ) の範囲における杭の曲げ座屈

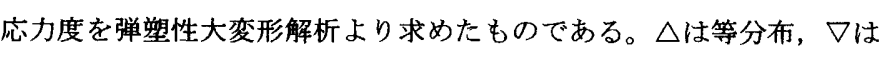
三角形分布を示している。横軸 $\sigma_{\mathrm{es}} \sigma_{\mathrm{er}} / \sigma_{\mathrm{y}}=0.5 \sim 0.75$ で, 非弾性地盤における 杭の曲げ座屈応力度は弾性地盤の場合に比べて低下している。これは, 図 9 (b) の平均軸歪一水平変位関係からも明らかなように, 図 7 で仮定 した $K_{\mathrm{c}}\left(\mathrm{y} / \mathrm{y}_{1}=1\right)$ と，鋼管杭が座屈して水平変形が急激に増加する時の $K_{\mathrm{c}}$ $\left(\mathrm{y} / \mathrm{y}_{1}=0.002 l \sim 0.003 l\right)$ が異なり, 杭の座屈発生時における非弾性地盤の地 盤反力係数が弾性地盤の場合よりも小さいためである。

そこで, 図 7 のような非弹性地盤の地盤反力変位関保において，座 屈発生時に最大となる水平変位を $u / l=0.002$ と仮定し，そのときの地盤 水平変位 $\mathrm{y} / \mathrm{y}_{1}$ におりる割線剛性を $K_{c}{ }^{\prime}$ とする。 $K_{c}{ }^{\prime}$ に対する $K_{\mathrm{c}}$ の比，す なわち地盤剛性の見か十上の低下率を次のように近似する。

$\chi=\sqrt{l_{0} / l}, \quad l_{0}=500(\mathrm{~cm})$

ここで, lは杭長, $l_{0}$ は $\mathrm{y} / \mathrm{y}_{1}=1$ となる $500 \mathrm{~cm}$ である。

表 2 に杭長 $l$ と低下率 $\chi$ の值を示す。表中 $\mathrm{y} / \mathrm{y}_{1}$ は座屈発生時の地盤水 平変位である。杭長が長くなるにつれて見かけ上地盤反力係数が低下 することから，杭の弾塑性曲げ座屈荷重を評価する際，修正された $K_{c}{ }^{\prime}$ を用いる必要がある。

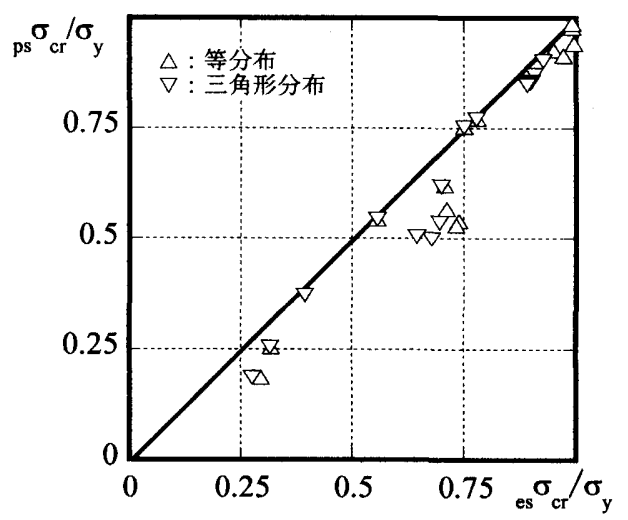

図 11 地盤反力変位関係及び地盤反力係数分布の違いが 弾塑性曲げ座屈応力度に及ぼす影響

表 2 非弾性地盤における地盤反力係数の低下率

\begin{tabular}{|c|c|c|c|c|}
\hline$l(\mathrm{~cm})$ & 500 & 1000 & 1500 & 2000 \\
\hline \hline $\mathrm{y} / \mathrm{y}_{1}$ at $=K_{\mathrm{c}}^{\prime}$ & 1.0 & 2.0 & 3.0 & 4.0 \\
\hline$\chi\left(=K_{\mathrm{c}}^{\prime} / K_{\mathrm{c}}\right)$ & 1.000 & 0.707 & 0.577 & 0.500 \\
\hline
\end{tabular}




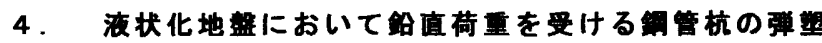 性曲げ座風応力度䚽価}

本章では，液状化地盤において鉛直荷重を受ける鋼管杭の弾塑性 曲げ座屈荷重の算定に当たり，現行の設計指針 ${ }^{8)}$, 設計基準 ${ }^{9)}$ にお ける圧縮材の耐力規定を淮用する可能性を検討する。

図 12 に鋼管杭の弾塑性座屈応力度と一般化細長比との関係を示 す。縦軸は曲げ座屈応力度 $\sigma_{\mathrm{or}}$ を降伏応力度 $\sigma_{\mathrm{y}}$ で除したものであり, 横軸は一般化細長比 $\lambda_{\mathrm{c}}$ である。杭の一般化細長比 $\lambda_{\mathrm{c}}$ は, その杭の弾 性座届荷重 $\mathrm{P}_{\mathrm{er}}$ に対する降伏荷重 $\mathrm{P}_{\mathrm{y}}$ の割合として次式で表される。

$$
\lambda_{\mathrm{c}}=\sqrt{\mathrm{P}_{\mathrm{y}} / \mathrm{P}_{\mathrm{cr}}}
$$

ここで, $P_{\alpha}$ はlの範囲によって, (7), (11), (12) 式の $\alpha$ を(6) 式に代入

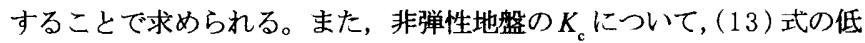
下率 $\chi に K_{\mathrm{c}}$ に乗じた修正值 $K_{c}{ }^{\prime}$ を用いて，座屈荷重 $\mathrm{P}_{\mathrm{cr}}$ を算定してい る。図中の実線は限界状態設計指針 ${ }^{81}$ の座屈曲線であり，点線は鎆構 造設計基淮 ${ }^{9}$ の座屈曲線である。各曲線の算定式は図中に示される 通りである。 $\lambda_{\mathrm{c}} \leqq 0.7$ では, 数値解析結果より得られた杭の曲げ座屈 荷重は鋼構造設計基準を上回っているが， $\lambda_{\mathrm{c}} \geqq 0.7$ では，概齐鋼構造 設計基準と限界状態設計指針の間に収まっている。

以上より，(6) 式で示した座屈荷重式を(14) 式の一般化細長比に用 いることで，通常の圧縮材と同様，限界状態設計指針を準用できる。

\section{5. 辐}

本論文では液状化地盤において，鉛直荷重を受ける鋮管単杭の曲 げ座屈について検討した。既往の研究では検討されていなかった杭 及び地盤反力係数の非線形性を考慮した数值解析を行い，杭の弾塑 性座屈挙動及び曲げ座屈态力度を評価した。解析対象の範囲は液状 化地盤を想定し, 地盤の変形係数 $\mathrm{E}_{0} \leqq 500\left(\mathrm{kN} / \mathrm{m}^{3}\right)$, 杭の細長比 $\lambda \leqq 150$ 以下もしくは液状化層厚 $20 \mathrm{~m}$ 以下である。本論文で得られた結論を 以下に示す。

1）エネルギー法及び弾性固有値解析によって，液状化地盤におい て鈆直荷重を受ける鋼管杭の弾性曲げ座屈荷重式を(6)式に示した。 さらに，地盤反力係数及びその分布の違いが鋼管杭の弹性曲げ座屈 荷重に与える影響を明らかにした。

2) 弾塑性大変形解析によって, 地盤反力变位関係の非線形性が杭 の弾塑性座屈荷重に及ぼす影響を明らかにした。地盤反力変位関係 が一定の場合に比べて，非線形の場合には $\sigma_{c r} / \sigma_{y}=0.5 \sim 0.75$ の範囲で座 屈荷重の低下が見られた。これは, 杭の座屈発生時における地盤反

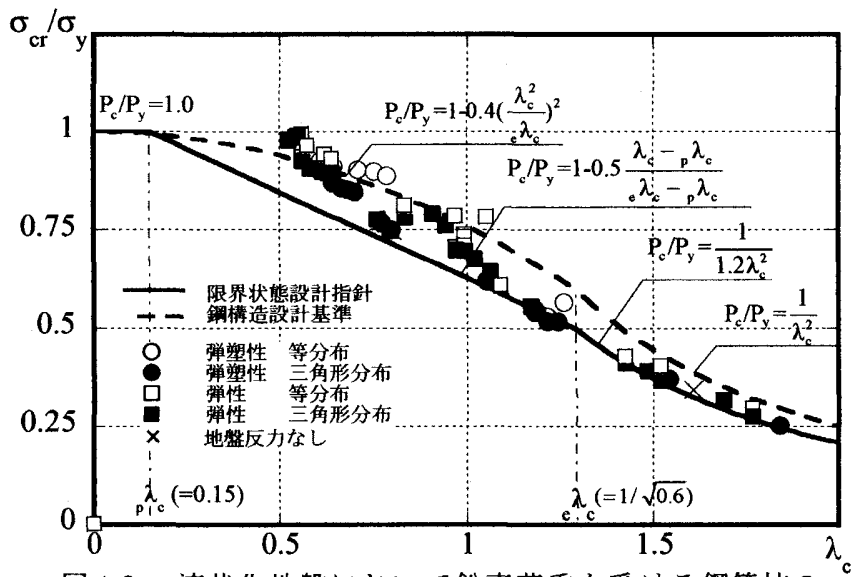

図 12 液状化地盤において鈆直荷重を受ける鋼管杭の 弾塑性曲げ座屈応力度と設計式の比較

力保数が低下しているためであり，その低下率を(13) 式に示した。 3）液状化地盤において，地盤により水平変形拘束を受ける鎆管杭 の弾塑性曲げ座屈荷重は, 細長比の小さい範囲 $\left(\lambda_{\mathrm{c}} \leqq 0.7\right)$ では限界 耐力設計指針の座屈設計式よりも上回るが，細長比の大きい範囲 $\left(\lambda_{\mathrm{c}} \geqq 0.7\right)$ では良い対応を示している。鋼管杭の許容圧縮応力度は， 本論文で提示した (14) 式の一般化細長比を用いることで, 通常の圧 縮材と同様，限界状態設計指針を準用できる。

\section{钭辞}

本研究の一部は平成 14 年度前田記念工学振興財団研究助成を 受けた。ここに感謝の意を表す。

\section{考女被}

1）日本建築学会：建築耐鹿設計における保有耐力と変形性能(1990)，1990.10 2）三浦房紀，朱媛媛：地盤の側方変位を受けている単杭の座屈荷重に関する 基硠的研究，土木学会論文集，pp. 143 pp. 153，2001.7

3）地盤工学会 : 地盤・基磷構造物の耐震設計，2001。1

4) Timoshenko:Elastic Stability, McGraw Hill, 1961

5) Prakash V., Powell G. H. and Campbell S. :Drain-2DX Base Program Desciption and User Guide Version 1. 10, 1993

6）木村祥裕，小河利行，佐伯英一郎：製造方法の異なる冷間成形鎆管の局部 座屈挙動，鋼構造論文集，第 8 巻第 29 号, pp. $27 \sim$ pp. $34,2001.3$

7）日本建築学会 : 基礎構造設計指針 ·同解説, 1988.1

8）日本建築学会：鋼構造限界状態設計指針・同解説, 1998.10

9）日本建築学会 : 鋼構造設計基準 ・同解説，1970 